\title{
Dissolved oxygen and nitrate of groundwater in Choshui Fan-Delta, western Taiwan
}

\author{
Wen-Fu Chen · Tsung-Kwei Liu
}

\begin{abstract}
Dissolved oxygen (DO) and nitrate concentrations of groundwater from a total of 191 new monitoring wells, with a maximum depth up to $300 \mathrm{~m}$, in the Choshui fan delta of Taiwan were measured to delineate the regional patterns of the two components. Unconfined aquifers of the proximal part of the fan delta contain $1 \sim 7 \mathrm{mg} / \mathrm{l}$ of DO, and a $250-\mathrm{m}$ deep well still has an unusual value of $1.83 \mathrm{mg} / \mathrm{l}$. DO concentrations decrease downgradient along flow paths to below detection limit $(0.01 \mathrm{mg} / \mathrm{l})$ in shallow confined aquifers during the last 40 years, possibly due to oxidation of organic matters in sediments. A plume of high nitrate- $\mathrm{N}$ concentrations $(0.5-17 \mathrm{mg} / \mathrm{l})$ originating from the proximal part of the fan delta has been developing, possibly since 1956, due to agricultural fertilizers. From 1997 to 2001, the concentration has increased at a rate of ca. $0.28 \mathrm{mg} / \mathrm{l}$ per year.
\end{abstract}

Keywords Dissolved oxygen - Fan-delta aquifer · Nitrate $\cdot$ Taiwan

\section{Introduction}

Oxidation-reduction (or redox) reactions in aquifers can lead to the formation of new mineral phases and changes of water compositions. The materials most often involved in redox reactions are organic matters, oxygen, nitrogen, sulfur, and heavy metals, such as iron and manganese. Meanwhile, many redox reactions are microbially

Received: 22 January 2003 / Accepted: 7 April 2003

Published online: 28 June 2003

(C) Springer-Verlag 2003

W.-F. Chen $(\varangle) \cdot$ T.-K. Liu

Department of Geosciences, National Taiwan University,

4, Lane 31, Chung Hsing Rd., 730 Hsin Ying, Taiwan

E-mail: alfalf@ms2.hinet.net

Tel.: +886-6-6324142

Fax: +886-6-6326642 mediated with different energy yields. In general, anaerobic reactions follow the redox sequence with decreasing oxidation potentials (Eh) and energy yields: so do DO-reduction, nitrate-reduction, Mn(IV)-reduction, $\mathrm{Fe}(\mathrm{III})$-reduction, sulfate-reduction, and methanogenesis (Stumm and Morgan 1995).

Marine sediment geochemists were the first to take this approach to describe redox zones, which were called diagenetic sequence (Froelich and others 1979). Similar approaches had been applied to groundwater systems. In a pristine aquifer, water percolating through the vadose zone contains oxygen under near air-saturated conditions. Below the water table, where gas exchange with the atmosphere ceases, DO is gradually consumed by microbial uptake, biodegradation of organic matters, and reactions with reduced mineral phases (Champ and others 1979). Organic matter contents of the fan-delta are generally high (2-10 wt\%) and considered as a major oxygenconsuming material. However, little information concerning redox zonation in fan-delta aquifers has been published.

The Choshui fan-delta is one of the most important groundwater resource areas in Taiwan and yields about $40 \%$ of the groundwater pumped from the whole island. Recently, high concentrations of nitrate in drinking groundwater from the proximal fan-delta have aroused severe public concerns. The purpose of this study is to delineate the oxygen- and nitrate-reduction zones in the early stage of the reduction sequence for the aquifers of the fan delta.

\section{Hydrogeology}

The Choshui fan delta, ca. $40 \mathrm{~km}$ long from the apex to the coast and $60 \mathrm{~km}$ wide along the coast, is composed of sediments mainly transported by the Choshui Stream (Fig. 1a). The topographic surface extends smoothly from an altitude of ca.100 $\mathrm{m}$ at the apex down to the sea level. From east to west, a thick unconsolidated gravel layer gradually change facies into finer sediments such as sands and clays (Fig. 1b). The upper-most 60-m-thick layer was deposited during Holocene, which, in turn, is underlain disconformably by late Pleistocene strata (CGS 1995). 

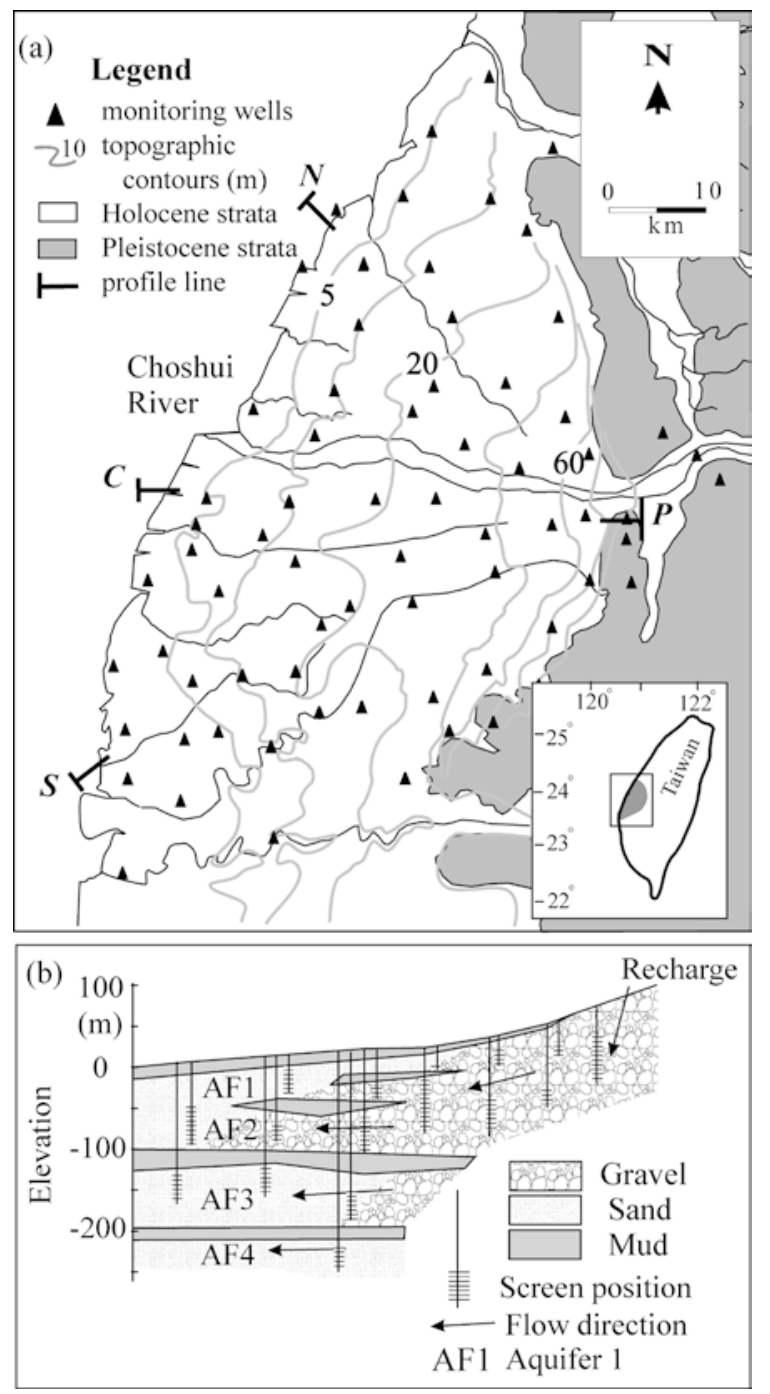

Fig. 1

a Locations of the monitoring wells and topography of the Choshui fan delta, Taiwan. b A hydrogeological profile $(C-P$ in the above figure) along the down stream of the Choshui river. $N-P$ and $S-P$ are profile lines for Fig. 3

The thick $(>250 \mathrm{~m})$ gravelly aquifer of the proximal part, as well as the uppermost $(<20 \mathrm{~m}$ depth) sandy aquifers in the middle-distal fan delta, are unconfined in hydrologic character. A thick and extensive mud layer, which is encountered at a depth of ca. $20 \mathrm{~m}$ in the middle fan, gradually increases seaward (Fig. 1b) and acts as the most important aquitard (named as Huchi aquitard; Liu 1995) of the middle and distal parts.

A total of 191 monitoring wells at 85 sites (Fig. 1a) were drilled during the period from 1991 to 1997 . The average distance between two neighboring sites is $3.5 \mathrm{~km}$. The deepest well is about $300 \mathrm{~m}$. Bentonite was used to seal each aquifer and care was taken to avoid mixing with water from the upper and lower aquifers.

Groundwater of the fan delta flows seaward in a pattern similar to the surface water (Fig. 2). The proximal part serves as the main recharge area for the confined aquifers in the down-gradient parts. All groundwater samples from
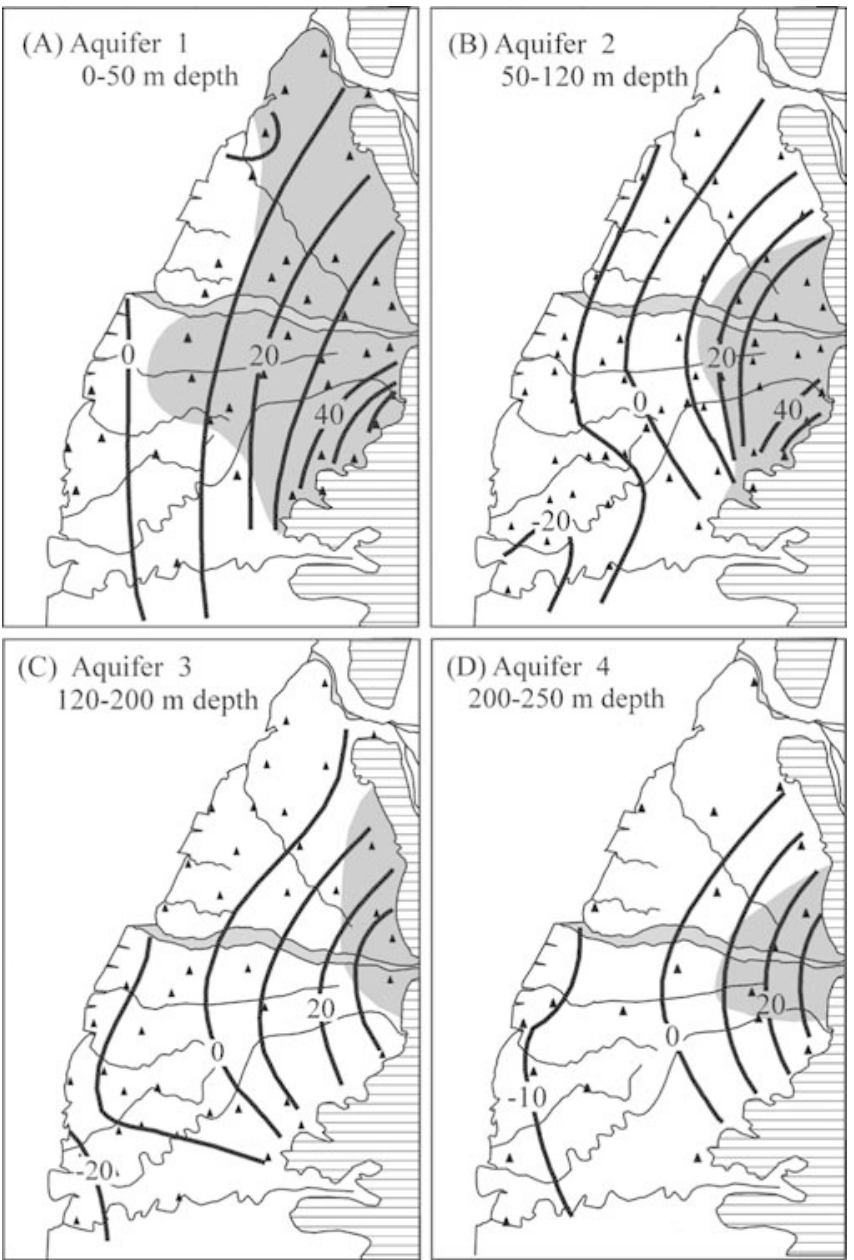

$\Delta$ Monitoring wells
-20 Contours $(\mathrm{m})$ of hydraulic head

Pleistocene outcrops Tritium $>1.0 \mathrm{TU}$

Fig. 2

Distribution of hydraulic head measured during the dry season (February of 1999) and tritium concentrations in different aquifers of the Choshui fan-delta. Shaded areas represent groundwater of $>1$ TU. Tritium data from Liu 1995

this recharge area have tritium concentration $>1 \mathrm{TU}$ (Liu 1995) and were considered to be recharged after the commencement of frequent nuclear bomb tests in ca. 1953.

\section{Analytical methods}

The field sampling methods follow the standard method of NIEA code W103.50B set out by the Taiwan Environment Protection Agency. Water that stagnant within the casing was pumped out three times and discarded before taking samples. Temperature, $\mathrm{pH}$, electrical conductivity (EC), hydraulic head, and turbidity were recorded every $5 \mathrm{~min}$ during purging. Samples were taken only after $\mathrm{pH}$ and EC became stable, i.e., the fluctuations of $\mathrm{pH}$ and relative $\mathrm{EC}$ were less than 0.1 and $5 \%$, respectively. 
Each water sample was then divided into several portions according to the need for chemical analyses. Those for cation measurements were filtered with $0.45-\mu \mathrm{m}$ glass fiber papers and acidified with nitric acid until the $\mathrm{pH}$ equaled 2. Samples were then kept in ice boxes and delivered to the laboratory within $24 \mathrm{~h}$. Concentrations of nitrate-N were determined by a cadmium-reduction colorimetric method (APHA 1998).

An oxygen-sensitive membrane electrode method (Carritt and Kanwisher 1959; APHA 1998) was widely used in DO measurements. Electrodes were preliminarily calibrated against air-saturated dissolved oxygen and then corrected for barometric pressure, temperature, and salinity. DO is continuously depleted at the electrode surface while infiltrating the membrane; thus, a downhole stirring device is required to circulate water outside the membrane. The instrument used was a MiniSonde, which was made by HydroLab in USA. (Use of brand names in this report is for identification purposes only and does not constitute endorsement by the authors.) The instrument is $5 \mathrm{~cm}$ in diameter and $70 \mathrm{~cm}$ in length, including a data logger, a circulator, and five sensors for temperature, EC, $\mathrm{pH}$, oxidation-reduction potential (ORP), and DO measurements, respectively. After purging, the MiniSonde was lowered down to the screen position of the well casing and remained there for at least $10 \mathrm{~min}$ before the data logger was set to record water quality parameters every $5 \mathrm{~min}$.

According to certification from the manufacturer, the detection limit of DO is $0.2 \mathrm{mg} / \mathrm{l}$ for the Minisonde. On the other hand, Radtke and others (1998) recommended a spectrophotometric method for determining DO of less than $1.0 \mathrm{mg} / \mathrm{l}$. This method is based on a Rhodazine-D colorimetric technique and has a sensitivity of $0.01 \mathrm{mg} / \mathrm{l}$ (ASTM 1984; White and others 1991). By comparing the results measured by the membrane method and the spectrophotometric method, concentrations measured by the membrane method became unreliable when they were less than $0.5 \mathrm{mg} / \mathrm{l}$.

For the sake of data quality control, the Winkler method (code 4500-OB, APHA 1998) was used to check those samples whose DO concentrations measured by Minisonde are larger than $0.5 \mathrm{mg} / \mathrm{l}$. As a result, 25 samples were analyzed by both methods and each pair of data are consistent within $\pm 0.5 \mathrm{mg} / \mathrm{l}$ error.

\section{Dissolved oxygen concentrations}

DO concentrations were measured during the periods from November to December of 1999 and July to August of 2000 , respectively. Of the total 166 samples, only 26 ( $16 \%$ samples) were greater than $0.5 \mathrm{mg} / \mathrm{l}$. Among the other 140 samples of DO less than $0.5 \mathrm{mg} / \mathrm{l}, 30$ samples were also measured by the Rhodazine-D method. It has been found that DO concentrations of all the 30 samples were below the detection limit $(0.010 \mathrm{mg} / \mathrm{l})$ of the latter method. For the purpose of simplification, the term

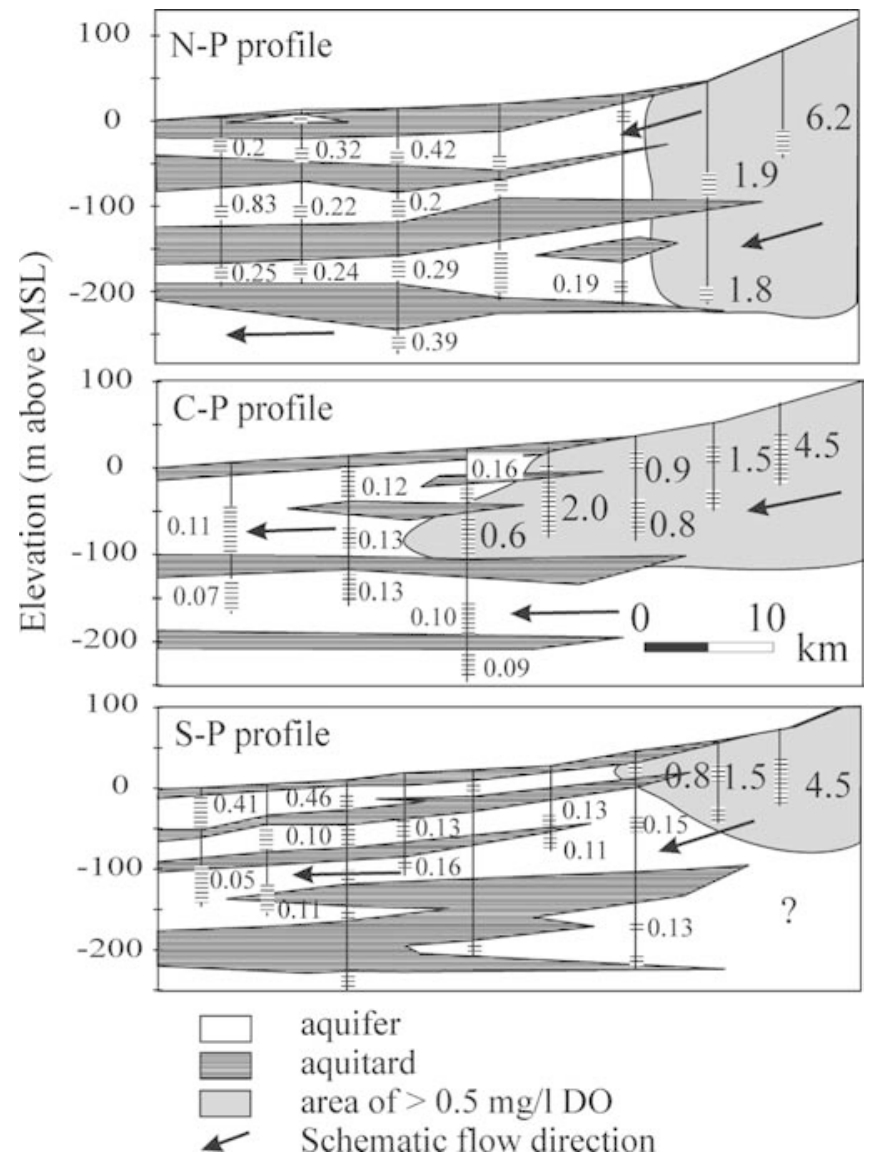

Fig. 3

Profiles of DO measured by the membrane electrode method for groundwater in the Choshui fan delta. Shaded area represents groundwater having $>0.5 \mathrm{mg} / \mathrm{l}$ of DO. It is obvious that DO decreases downgradient. Profile lines are indicated in Fig. 1

"oxic" is used to describe $\geqq 0.5 \mathrm{mg} / \mathrm{l}$ of DO and "anoxic" $<0.5 \mathrm{mg} / \mathrm{l}$.

Except for very shallow unconfined wells in the middle and distal parts of the Choshui fan delta, almost all wells of high DO concentrations are screened at thick $(>200 \mathrm{~m})$ unconfined aquifers in the proximal part (Figs. 3 and 4). Downgradient from the apex of the fan, DOs decrease from the maximum of 6.22 to $1-2 \mathrm{mg} / \mathrm{l}$ at ca. $5 \mathrm{~km}$ and $<0.5 \mathrm{mg} / \mathrm{l}$ at ca. $10 \mathrm{~km}$, respectively. Except one, each oxic well has slightly higher DO concentration during the wet season (July 2000) than the prior dry season (November 1999; Fig. 5).

Eh values of oxic and anoxic groundwaters from the Choshui fan delta were $200-0$ and 0 to $-400 \mathrm{mV}$, respectively (Fig. 6). These Eh values of oxic groundwaters are considerably lower as compared with $200-400 \mathrm{mV}$ for the Triassic Sherwood sandstone aquifer in the UK (Smedley and Edmunds 2002) and Tucson Basin aquifer in the USA (Rose and Long 1988). It is worth comparing the dissolved organic carbon (DOC) of the Choshui fan delta (0.4-2 $\mathrm{mg} / \mathrm{l}$ ) with that of the Sherwood sandstone aquifer (ca. $<0.12 \mathrm{mg} / \mathrm{l}$ ). This may imply that higher DOC results in lower Eh value. 

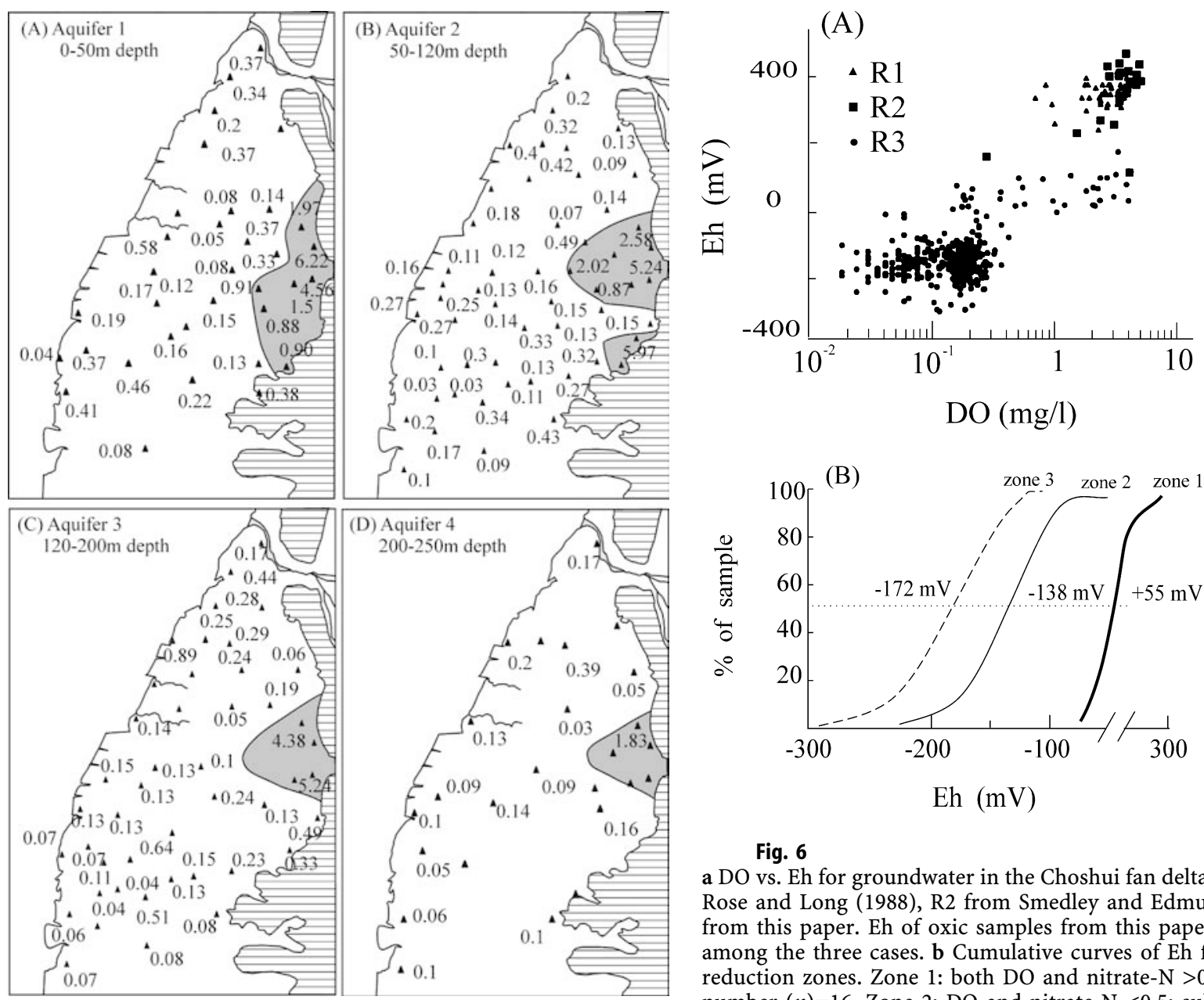

Fig. 4

DO (in $\mathrm{mg} / \mathrm{l}$ ) measured by the membrane electrode method for the Choshui fan delta; shaded areas represent $>0.5 \mathrm{mg} / \mathrm{l}$

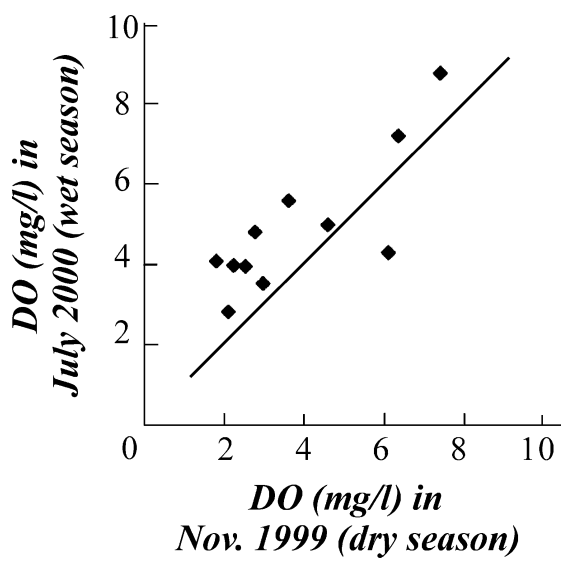

Fig. 5

Comparison of DO concentrations in 11 well water samples from unconfined aquifers measured in wet and dry season. Except one well, DO in the wet season, is ca. $1-2 \mathrm{mg} / \mathrm{l}$ higher than in the dry season for the same well

In terms of DO, nitrate, and sulfide contents in groundwaters, aquifers in the Choshui fan delta can be divided into three redox zones. All the 16 samples from the first (or

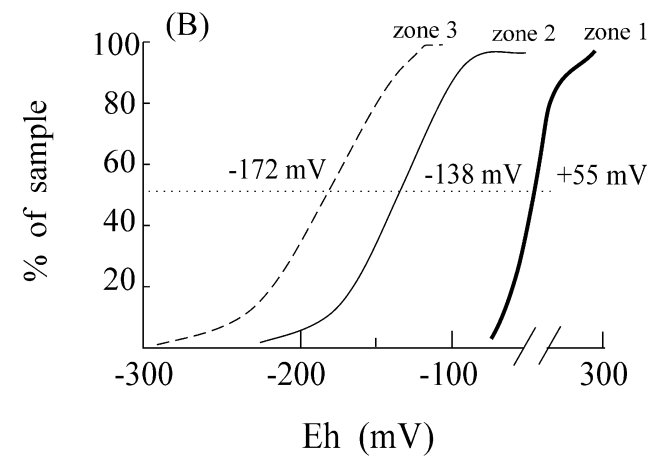

Fig. 6

a DO vs. Eh for groundwater in the Choshui fan delta. Data of R1 from Rose and Long (1988), R2 from Smedley and Edmunds (2002), R3 from this paper. Eh of oxic samples from this paper were lowest among the three cases. $\mathbf{b}$ Cumulative curves of Eh for different reduction zones. Zone 1: both $\mathrm{DO}$ and nitrate- $\mathrm{N}>0.5 \mathrm{mg} / \mathrm{l}$, sample number $(n)=16$. Zone 2: DO and nitrate- $\mathrm{N}<0.5$; sulfide $>0.03 \mathrm{mg} / \mathrm{l}$, $n=46$. Zone 3: both DO and nitrate-N $<0.5$; sulfide $<0.03 \mathrm{mg} / \mathrm{l} ; n=129$. The median Eh value for each curve decreases from +55 (zone 1) to $172 \mathrm{mV}$ (zone 3)

proximal) zone are oxic and nitrate-N greater than $0.5 \mathrm{mg} /$ 1. The 46 samples of the second zone are anaerobic and total dissolved sulfide greater than $0.03 \mathrm{mg} / \mathrm{l}$. Finally, the 129 samples from the third zone are anaerobic without detectable sulfide. The median of Eh values for the three zones decreases downgradient from +55 , to 138 , to $172 \mathrm{mV}$, respectively (Fig. 6b).

Many studies have shown that rates of DO removal depend on local hydrogeology (e.g., Heaton and Vogel 1980; Edmunds and others 1982; Winograd and Roberson 1982). The Choshui fan-delta provides a good opportunity to compare the DO consumption rates for aquifers of different lithologies; with gravel in the proximal fan and sand/mud in the middle and lower parts. Recent groundwater as indicated by $>1 \mathrm{TU}$ of tritium content in the proximal fan is still oxic, whereas the 21 wells screened at shallow aquifers in the middle fan have been reduced to less than $0.5 \mathrm{mg} / \mathrm{l}$ (Fig. 7).

Many researches have shown that DOC is an important material to consume DO (Molz and others 1986; Ronen and others 1987). However, an apparent negative correlation between DOC and DO has not been found in the Choshui fan delta, probably because its DOC is too low (i.e., less than $2 \mathrm{mg} / \mathrm{l}$ ) to consume DO. On the contrary, 


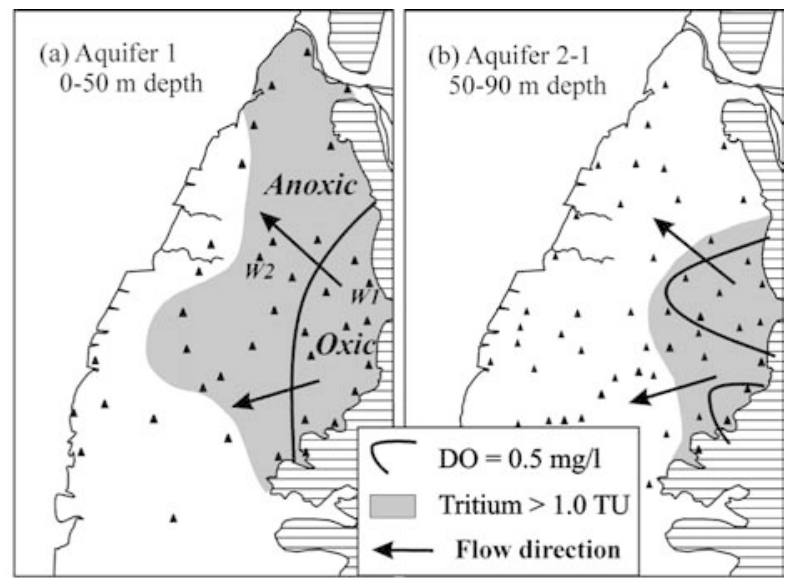

(c)

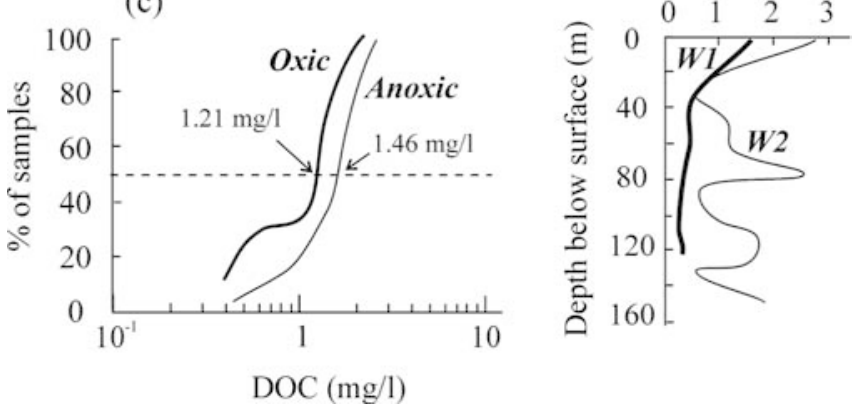

Fig. 7

a, b DO and tritium concentrations of aquifers 1 and 2. Recently recharged groundwaters (tritium $>1.0 \mathrm{TU}$ ) were further classified as oxic (DO $>0.5 \mathrm{mg} / \mathrm{l}$ ), or anoxic (DO $<0.5 \mathrm{mg} / \mathrm{l}$ ). c Cumulative curves for DOC of recently recharged groundwater. The difference of DOC between oxic and anoxic samples are not large. $\mathbf{d}$ Sediment organic matters (SOM) contents are higher in the middle and the lower parts as exemplified by well \#W2 than that in the proximal parts as represented by well \#W1

some samples are high in DO and DOC (2-2.5 mg/l), probably because DOC is not yet thermodynamically equilibrated with DO, or a large portion of DOC has been inert for microbial oxidation.

Fine sand and clay formations generally contain more organic matter than gravel formations (Tyson 1995). The average organic matter content $(1.5 \mathrm{wt} \%)$ of sediments in middle fan aquifers (e.g. borehole \#W2) of finer grained sand and clay is greater than that in proximal fan aquifers of gravel (e.g., $0.5 \mathrm{wt} \%$ of borehole \#W1; Fig. $7 \mathrm{~d}$ ). The authors suggest that the lower DO consumption rate in proximal fan aquifers may depend on the lower organic matter contents in the sediments.

\section{Nitrate concentrations}

Generally, nitrogen as ammonia and in organic matter is converted to nitrate in oxic groundwater. Nitrate- $\mathrm{N}$ concentrations have been found to be greater than $0.5 \mathrm{mg} / \mathrm{l}$ for the unconfined aquifer in the proximal area, where DO was also high (Fig. 8). The area was over $100 \mathrm{~km}^{2}$ during the

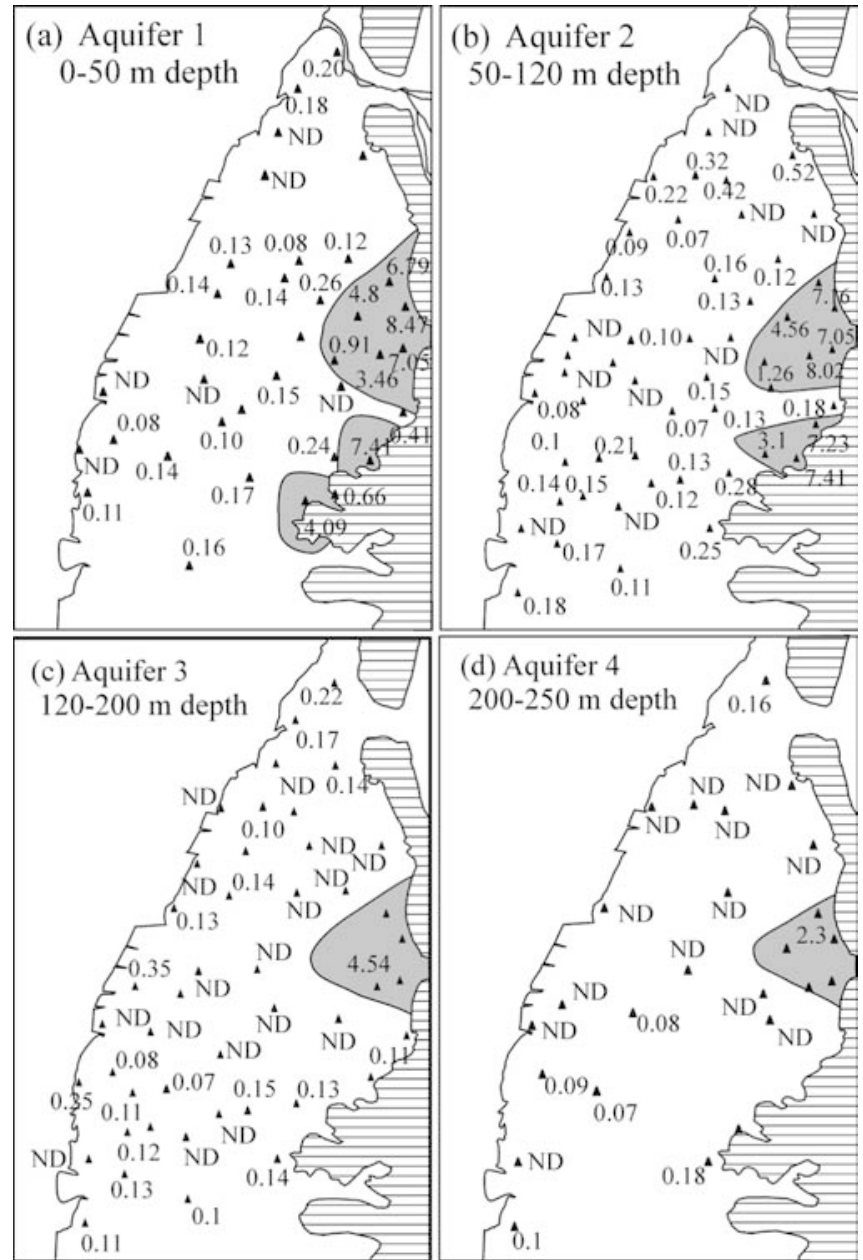

Fig. 8

Nitrate- $\mathrm{N}$ concentrations (in $\mathrm{mg} / \mathrm{l}$ ) of groundwater in various aquifers of the Choshui fan delta as measured in November 1999. Groundwater with nitrate- $\mathrm{N}$ than $0.5 \mathrm{mg} / \mathrm{l}$ was recharged from the proximal part

1999-2000 investigation period. However, only two of the 60 deep $(>100 \mathrm{~m})$ wells had greater than $0.5 \mathrm{mg} / \mathrm{l}$ of nitrate-N in 1956 (Fig. 9; AMOMO 1957). In addition, well \#TJ has showed a sharp increasing trend since 1992 (Fig. 10).

The nitrate concentrations of groundwater in the Choshui fan delta decrease along flow paths. For example, Fig. 8a shows that nitrate- $\mathrm{N}$ decreases from $8.47 \mathrm{mg} / \mathrm{l}$ in the proximal fan to 4.8 and $0.26 \mathrm{mg} / \mathrm{l}$ at 5 and $10 \mathrm{~km}$ downgradient, respectively. Downgradient denitrification cannot account for this trend because DO contents of the low-nitrate groundwater are still high. Smith-Carrington and others (1983) reported a similar case from a chalk aquifer in Britain and suggested that the downgradient decrease of nitrate in oxic groundwaters may be related to downgradient dispersion and dilution.

From 1997 to 2001, nitrate concentrations in 34 monitoring wells in the upper fan-delta were monitored annually. Nitrate-N concentrations ranged from 0.47 to $17.8 \mathrm{mg} / \mathrm{l}$. The median of each accumulative curve (Fig. 11) for nitrate concentration increases steadily from 0.47 (1997), 1.26 (1999), 1.56 (2000), to $1.82 \mathrm{mg} / \mathrm{l}$ (2001), respectively. 


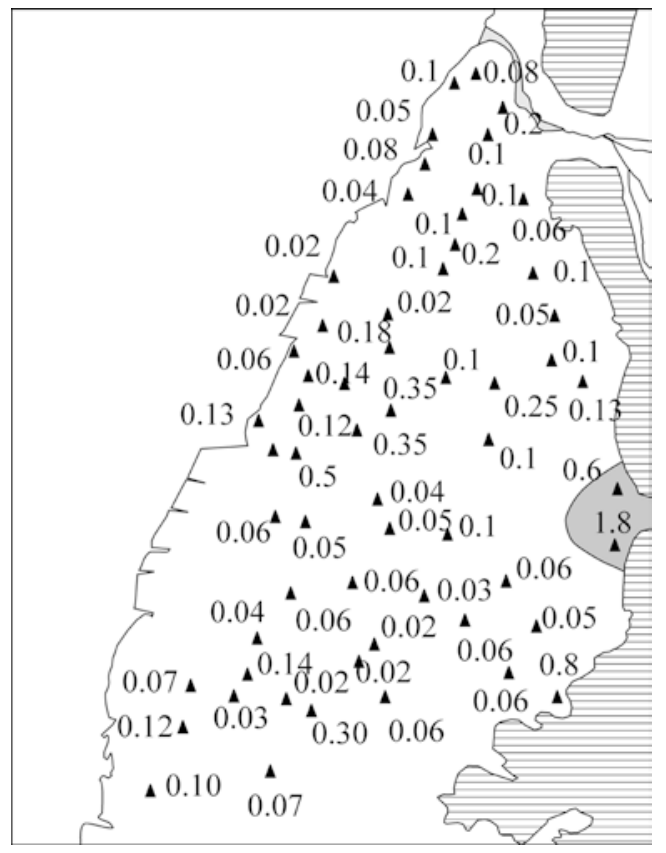

Fig. 9

Nitrate-N concentrations (in $\mathrm{mg} / \mathrm{l}$ ) measured in 1956 for groundwater at depths of ca. $150 \mathrm{~m}$ (data from AMOMO 1957). The shaded area indicates concentrations of $>0.5 \mathrm{mg} / \mathrm{l}$

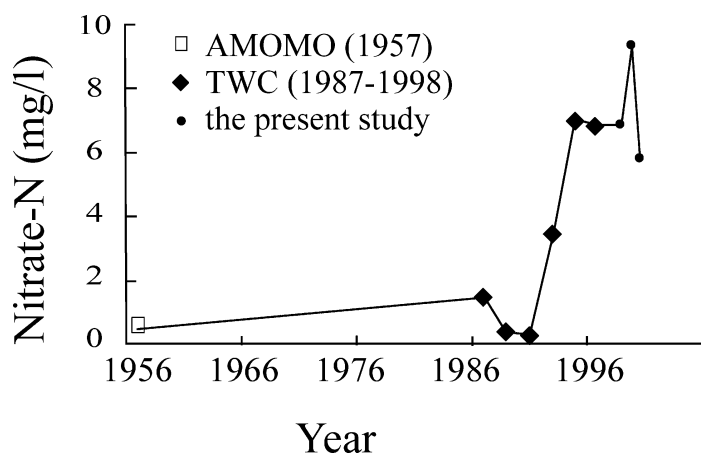

Fig. 10

Nitrate-N concentrations of well \#TJ in the proximal fan delta

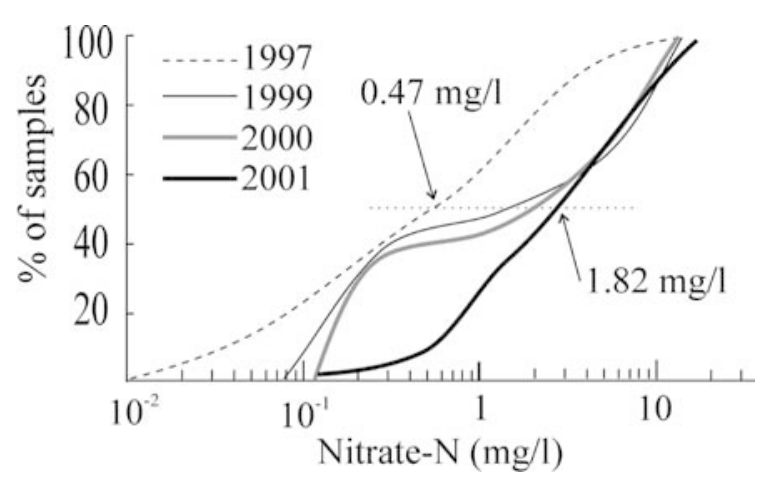

Fig. 11

Cumulative curves for nitrate-N concentrations from 1997 to 2001. Total samples number $=34$

\section{Conclusions}

Systematic investigations showed that groundwater in the unconfined proximal aquifer of the Choshui fan-delta contains $1-7 \mathrm{mg} / \mathrm{l}$ of dissolved oxygen and a value of $1.83 \mathrm{mg} / \mathrm{l}$ was obtained for the $250-\mathrm{m}$ depth. In contrast, dissolved oxygen in the shallow confined aquifers of the middle and distal parts was reduced, possibly by plant detritus to below $0.01 \mathrm{mg} / \mathrm{l}$ of the detection limit within the last 40 years.

A plume of high nitrate- $\mathrm{N}$ concentrations $(0.5-17 \mathrm{mg} / \mathrm{l})$ has been developing in the proximal part probably since 1956. Spatial distributions of detectable nitrate and dissolved oxygen almost coincide with each other. From 1997 to 2001, the groundwater nitrate- $\mathrm{N}$ concentrations showed a steady increasing trend of $0.28 \mathrm{mg} / \mathrm{l}$ per year from 0.47 to $1.82 \mathrm{mg} / \mathrm{l}$. The plume is attributed to agricultural fertilizers and is expected to grow if the present situation of land use continues.

Acknowledgements The authors wish to thank Mr. W.S. Chen of the Water Quality Lab of Taiwan Sugar Company for his useful comments and suggestions. This study is financially supported by Water Resource Bureau, MOEA, Taiwan.

\section{References}

AMOMO (1957) Investigation report on ground water resource of the Choshui fan. Joint Commission on Rural Reconstruction, Taiwan

APHA (1998) Standard methods for the examination of water and waste water, 20th edn. American Public Health Assoc, Washington, DC, pp 413-426

ASTM (1984) Power plant water analysis manual, 1st edn. American Society of Test Materials, Philadelphia, ch 38, pp 169-171

Carritt DE, Kanwisher JW (1959) An electrode system for measuring dissolved oxygen. Anal Chem 31:318-325

CGS (Central Geological Survey of Taiwan) (1995) Hydrogeology of the Choshui fan, Taiwan. Taipei, Taiwan

Champ DR, Gulens J, Jackson RE (1979) Oxidation-reduction sequences in ground water flow systems. Can J Earth Sci 16: $12-23$

Edmunds WM, Bath AH, Miles DL (1982) Hydrochemical evolution of the East Midlands Triassic sandstone aquifer, England. Geochim Cosmochim Acta 46:2069-2081

Froelich PN, Klinkhammer GP, Bender ML (1979) Early oxidation of organic matter in pelagic sediments of the eastern equatorial Atlantic: suboxic diagenesis. Geochim Cosmochim Acta 43:1075-1090

Heaton THE, Vogel JC (1980) Rate of oxygen removal in some South African groundwaters. Hydrol Sci Bull 25(4):373-377

Liu TK (1995) Estimating flow and recharge rates of groundwater in western Taiwan using radiocarbon and tritium. Radiocarbon 37(2):531-542

Molz FJ, Widdowson MA, Benefield LD (1986) Simulation of microbial growth dynamics coupled to nutrient and oxygen transport in porous media. Water Resour Res 22:1207-1216

Radtke DB, White AF, Davis JV, Wilde FD (1998) Dissolved oxygen. In: Wilde FD, Radtke DB (eds) Handbooks for waterresources investigations, ch A6, field measurements. US Geol Surv 
Ronen D, Magaritz M, Almon E, Amiel AJ (1987) Anthropogenic anoxification of the water table region of a deep phreatic aquifer. Water Resour Res 23:1554-1560

Rose S, Long A (1988) Dissolved oxygen systematics in the Tucson Basin Aquifer. Water Resour Res 24:127-136

Smedley PL, Edmunds WM (2002) Redox patterns and traceelement behavior in the East Midlands Triassic Sandstone aquifer, UK. Ground Water 40(1):44-58

Smith-Carrington AK, Bridge LR, Robertson AS, Foster SD (1983) The nitrate pollution problem in groundwater supplies from Jurassic Limestones in Central Lincolnshire. Institute Geological
Sciences Report 83-3, London, UK. Natural Environmental Research Council

Stumm W, Morgan JJ (1995) Aquatic chemistry: chemical equilibria and rates in natural waters, 3rd edn. Wiley, New York

Tyson RV (1995) Sedimentary organic matter. Chapman and Hall, London

White AF, Peterson ML, Solbau RD (1991) Measurement and interpretation of low levels of dissolved oxygen in ground water. Ground Water 28:584-590

Winograd IJ, Robertson FN (1982) Deep oxygenated ground water: anomaly or common occurrence. Science 216:1227-1230 